\title{
Motivasi Peserta Didik Sekolah Dasar Dalam Pembelajaran Pendidikan Jasmani Olahraga Dan Kesehatan Selama Masa Pandemi
}

\author{
Motivation of elementary school students in learning of physical \\ education, sport and healt during pandemic
}

\author{
Muhamad Ardonansyah ", Bayu Hardiyono, Arif Hidayat \\ Studi Pendidikan Olahraga, Universitas Bina Darma, Jl. Jendral Ahmad Yani, Kec Seberang Ulu I, Sumatera \\ Selatan, 30111, Indonesia. \\ e-mail: muhamadardonansyah@gmail.com, bayu.hardiyono@binadarma.ac.id, arif.hidayat@binadarma.ac.id.
}

\begin{abstract}
Abstrak
Penelitian ini bertujuan untuk mengetahui motivasi peserta didik sekolah dasar dalam pembelajaran Pendidikan jasmani olahraga dan kesehatan selama masa pandemi. Populasi dalam penelitian ini sekolah dasar Se-Kecamatan Ilir Timur I palembang yang berjumlah 15 sekolah dasar. Hasil penelitian motivasi peserta didik menunjukan bahwa $100 \%$ guru tetap memberikan motivasi belajar kepada peserta didik selama masa pandemi dan guru memberikan jawaban dengan cara memberikan salam sehat dan semangat kepada peserta didik selama masa pandemi. Proses pembelajaran PJOK menunjukan bahwa 100\% guru bekerjasama dengan orang tua agar pembelajaran PJOK terlaksana dengan baik selama masa pandemi dan memberikan tutorial melalui video dan PowerPoint untuk peserta didik belajar pembelajaran PJOK selama masa pandemi. Kendala belajar menunjukan 93,3\% guru belum menguasai penggunaan media daring dalam melaksanakan pembelajaran PJOK selama masa pandemi, guru kesulitan dalam mengakses internet dalam melaksanakan pembelajaran PJOK selama masa pandemi dan guru memberikan jawaban lainnya berupa tidak bisa praktik langsung, alat bantu mengajar kurang memadai, susah bagi anak yang tidak memiliki hp atau tidak mempunyai kouta untuk belajar, tidak ada kesulitan, sulit berkomunikasi kepada siswa yang tidak punya handphone. Diharapkan agar kedepanya guru olahraga tetap memberikan motivasi serta pembelajaran PJOK bervariatif dimasa pandemi.
\end{abstract}

Kata kunci: Motivasi, Pembelajaran PJOK, Pandemi

\begin{abstract}
This study aims to determine the motivation of elementary school students in learning physical education, sports and health during the pandemic. The population in this study was 15 elementary schools in Ilir Timur I Subdistrict, Palembang The results of the study on student motivation show that $100 \%$ of teachers continue to provide learning motivation to students during the pandemic and of teachers provide answers by giving healthy greetings and enthusiasm to students during the pandemic. The PJOK learning process showed that $100 \%$ of teachers collaborated with parents so that PJOK learning was carried out well during the pandemic and provided tutorials through videos and powerpoints for students to learn PJOK learning during the pandemic. Learning constraints show 93,3\% of teachers have not mastered the use of online media in implementing corner learning during the pandemic, of teachers have difficulty accessing the internet in carrying out PJOK learning during the pandemic and of teachers provide other answers in the form of not being able to practice directly, teaching aids are lacking adequate, difficult for children who do not have cellphones or do not have quotas to study, there are no difficulties, it is difficult to communicate with students who do not have cellphones. It is hoped that in the future sports teachers will continue to provide motivation and varied PJOK learning during the pandemic.
\end{abstract}

Keywords: Motivation, PJOK learning, Pandemic.

corresponding author: : muhamadardonansyah@gmail.com

Artikel Info:

Submitted: 22/09/2021

Revised : 28/10/2021

Accepted : 10/11/2021

Published: 15/11/2021 


\section{A. Pendahuluan}

Pendidikan merupakan hal pokok yang dapat menopang kemajuan suatu bangsa, tanpa Pendidikan suatu Negara akan jauh tertinggal dari Negara-Negara lain (Hardiyono, 2020). Pendidikan pada dasarnya merupakan usaha sadar dan terencana untuk mewujudkan suasana belajar dan proses pembelajaran agar peserta didik secara aktif mengembangkan potensi dirinya untuk memiliki kekuatan spiritual keagamaan, pengendalian diri, kepribadian, kecerdasan, akhlak mulia, serta keterampilan yang diperlukan dirinya, masyarakat, bangsa dan negara (Undangundang RI No. 20, 2003, 2003).

Olahraga pendidikan diselenggarakan sebagai bagian proses pendidikan dan dilaksanakan baik jalur pendidikan formal atau nonformal melalui kegiatan intrakurikuler dan/atau ekstrakurikuler (Hardiono, 2018). Olahraga pendidikan sering disebut dan dikenal berapa kalangan juga dengan pendidikan jasmani. Pendidikan jasmani juga bagian dari pendidikan secara keseluruhan yang mengutamakan aktivitas jasmani dan pembinaan hidup sehat untuk pertumbuhan dan perkembangan jasmani, mental, sosial, dan emosional yang serasi, selaras dan seimbang (Hidayat, 2019).

Dengan demikian untuk mencapai tujuan pendidikan jasmani tersebut guru merupakan unsur pelaksana teknis utama yang bertugas dan bertanggung jawab menjalankan kegiatan proses pembelajaran. Pendidikan jasmani olahraga kesehatan pada hakikatnya adalah proses pendidikan yang memanfaatkan aktivitas fisik dan kesehatan untuk menghasilkan perubahan holistik dalam kualitas individu, baik dalam hal fisik, mental serta emosional (Hidayat, A. 2019).

Pada saat ini dunia dilanda wabah coronavirus yang sering disebut juga COVID-19. Pandemi yang tejadi diseluruh Negara termasuk juga Indonesia yang berdampak pada berbagai bidang termasuk pendidikan (Herlina \& Suherman, 2020). Saat ini dunia pendidikan sedang menghadapi permasalahan yang cukup kompleks. Tentunya tidak banyak kendala pada jenjang sekolah menengah atas yang terbiasa menerapkan pembelajaran online, namun tidak demikian dengan jenjang pendidikan dasar yang bahkan tidak diperbolehkan membawa perangkat komunikasi (handphone) ke sekolah (Susilo et al., 2020).

Pandemi adalah wabah penyakit jenis baru yang belum pernah diidentifikasi sebelumnya pada manusia (Firman \& Rahayu, 2020). Tanggal 30 januari 2020 WHO telah menetapkan sebagai kedaruratan kesehatan masyarakat yang http://ejurnal.ubharajaya.ac.id/index.php/JCESPORTS 
meresahkan dunia. Indonesia pada tanggal 24 Maret 2020 melalui Menteri Pendidikan dan Kebudayaan Republik Indonesia mengeluarkan surat edaran nomor 4 tahun 2020 tentang pelaksanaan kebijakan pendidikan dalam masa darurat penyebaran pandemi COVID 19 (Handayani et al., 2020). Seperti saat ini karena adanya pandemi yang dimana virus ini memiliki penyebaran yang cukup cepat sehingga membuat pelaksanaan pembelajaran dilaksanakan secara daring (Herlina \& Suherman, 2020).

Dalam masa pandemi ini dimana semua aktivitas pembelajaran dilakukan dirumah melalui pembelajaran daring. Hasil temuan awal berdasarkan wawancara yang melibatkan beberapa guru-guru PJOK disekolah dasar menyatakan bahwa masih belum mengetahui seberapa besar motivasi peserta didik dalam mengikuti pembelajaran PJOK. Dikarenakan, guru belum dapat melakukan evalusi mengenai motivasi peserta didik dalam mengikuti pembelajaran mata pelajaran PJOK dimasa pandemi.

Motivasi adalah kondisi psikologi yang mendorong seseorang untuk melakukan sesuatu (Fitriyani et al., 2020). Dalam bidang pendidikan motivasi tentunya berorientasi pada pencapaian kondisi psikologi yang mendorong seseorang untuk semangat dalam belajarnya
(Kusmiyanti et al., 2018).

Motivasi juga dikatakan suatu perubahan energi yang terjadi pada individu yang ditandai dengan timbulnya perasaan dan reaksi atau tindakan untuk mencapai tujuan tertentu (Mariani et al., 2019). Menurut Huang \& Hsu, (2019) motivasi merupakan sebagai kekuatan (energi) seseorang yang dapat menimbulkan kemauan dalam melaksanakan suatu kegiatan. Kemauan baik yang bersumber dari dalam diri individu itu sendiri (Motivasi intrinsik) maupun dari luar individu (Motivasi ekstrinsik).

Merujuk pada penelitian terdahulu yang dilakukan oleh (Priono, 2021) beliau menyatakan pada masa pandemi, 100\% guru tetap memberikan pembelajaran PJOK, 66,7\% guru menggunakan metode pembelajaran daring, 38,9\% pembelajaran PJOK sesuai dengan RPP dan $38.9 \%$ sesuai RPP namun tidak runtut. Selajutnya untuk hasil media yang digunakan dalam pembelajaran PJOK, $100 \%$ guru menggunakan media pembelajaran dengan aplikasi whatsapp group, lalu 94\% peserta didik antusias dan berpartisipasi baik dalam pembelajaran

Berdasarkan latar belakang yang telah dikemukakan pada pembahasan sebelumnya maka, penulis berkeinginan menganalisis tekait Motivasi Peserta 
Motivasi Peserta Didik Sekolah Dasar Dalam Pembelajaran Pendidikan Jasmani Olahraga Dan

Kesehatan Selama Masa Pandemi

E-ISSN: 2722-3450 P-ISSN: 2775-3808

Didik Sekolah Dasar Dalam Pembelajaran

PJOK Selama Masa Pandemi sebagai upaya untuk meningkatkan Pembelajaran pendidikan jasmani olahraga dan kesehatan bagi peserta didik sekolah dasar Se-Kecamatan Ilir Timur I palembang selama masa pandemi.

\section{B. Metode Penelitian}

Penelitian ini menggunakan metode deskriptif kuantitatif. Sedangkan analisis data bersifat kuantitatif statistik untuk menguji hipotesis yang ditetapkan. Metode penelitian menggunkan metode survei dan pengumpulan datanya menggunakan kuesioner secara online melalui google form dengan pendekatan one shot case study (Ceruso et al., 2019).

Populasi penelitian ini 15 sekolah dasar Se-Kecamatan Ilir Timur 1 Palembang, sedangkan sampel yang mewakili sebanyak 30 guru PJOK. Pengambilan sampel menggunakan teknik probability sampling dengan metode pendekatan simple random sampling (Sugiyono, 2015).

Sebelum melakukan kegiatan penulis melakukan observasi dan membuat angket dengan menggunakan aplikasi google formulir. Jawaban atas pertanyaan yang dibuat secara otomatis masuk ke email.
Tabel 1. Intrumen Penelitian berbentuk

Kuesioner

\begin{tabular}{|c|c|}
\hline No & Pertanyaan untuk Guru \\
\hline 1. & $\begin{array}{l}\text { Apakah motivasi yang diberikan } \\
\text { adalah motivasi belajar bagi peserta } \\
\text { didik selama masa pandemi ? }\end{array}$ \\
\hline 2. & $\begin{array}{l}\text { Apakah peserta didik tertarik saat } \\
\text { diberikan semangat dalam } \\
\text { mengerjakan tugas PJOK selama } \\
\text { masa pandemi? }\end{array}$ \\
\hline 3. & $\begin{array}{l}\text { Apakah selama masa pandemi } \\
\text { peserta didik memiliki minat belajar } \\
\text { PJOK ? }\end{array}$ \\
\hline 4. & $\begin{array}{l}\text { Apakah memberikan dorongan } \\
\text { belajar kepada peserta didik efektif } \\
\text { dalam pembelajaran PJOK selama } \\
\text { masa pandemi? }\end{array}$ \\
\hline 5. & $\begin{array}{l}\text { Apakah memberikan pemahaman } \\
\text { disetiap pembelajaran PJOK kepada } \\
\text { peserta didik mampu meningkatkan } \\
\text { kemauan mereka belajar selama } \\
\text { masa pandemi? }\end{array}$ \\
\hline
\end{tabular}

\section{Hasil dan Pembahasan}

Hasil Penelitian yang dilakukan di sekolah dasar Se-Kecamatan Ilir Timur I Palembang untuk mengetahui motivasi peserta didik sekolah dasar pada pembelajaran PJOK selama masa pandemi.

Data diperoleh dengan menggunakan kuesioner yang berisi pertanyaan untuk mengetahui motivasi peserta didik sekolah dasar pada pembelajaran PJOK selama masa pandemi.

Tabel 2. Indikator motivasi peserta didik

\begin{tabular}{lrr}
\hline \multicolumn{1}{c}{ Jawaban } & \multicolumn{1}{c}{ Frekuensi } & \multicolumn{1}{c}{ Persentase } \\
\hline Ya & 29 & 96.7 \\
\hline Tidak & 0 & 0 \\
\hline Lainnya & 1 & 3.3 \\
\hline Total & 30 & 100.0 \\
\hline
\end{tabular}

Sumber: Hasil Pengolahan Data (2021) 


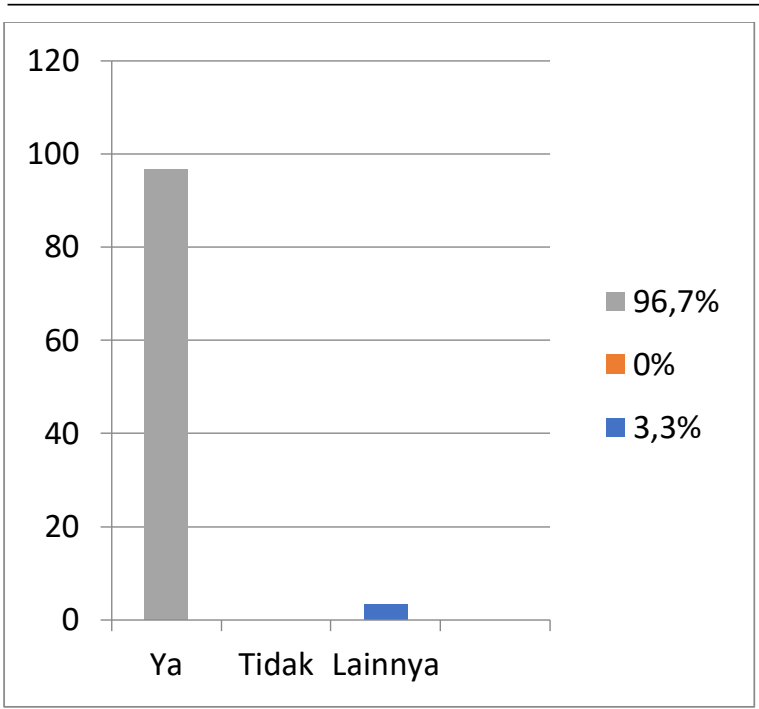

Gambar 1. Gambar Diagram Batang Motivasi Peserta Didik

Berdasarkan tabel dan gambar diatas dapat diketahui bahwa pada kondisi pandemi ini, 96,7\% guru tetap memberikan motivasi belajar kepada peserta didik selama masa pandemi dan $3,3 \%$ guru memberikan jawaban berupa dengan cara memberikan salam sehat dan semangat kepada peserta didik selama masa pandemi.

Tabel 3. Hasil Kuesioner Dari Data Excel

\begin{tabular}{|c|c|c|c|c|c|}
\hline & $\begin{array}{c}\text { MOTIVASI } \\
\text { PESERTA } \\
\text { DIDIK }\end{array}$ & $\begin{array}{c}\text { METODE } \\
\text { PEMBELA } \\
\text { JARAN }\end{array}$ & $\begin{array}{c}\text { KESESUAIAN } \\
\text { MATERI } \\
\text { PEMMELAJARA } \\
\mathrm{N} \\
\end{array}$ & \begin{tabular}{|l|} 
MEDLA \\
PEMBEL \\
AJARAN
\end{tabular} & \begin{tabular}{|c} 
PARTISIPAS \\
PESERTA \\
DIDIK
\end{tabular} \\
\hline VAUD & 30 & 30 & 3 & 30 & 30 \\
\hline N MISSING & 0 & 0 & & 0 & 0 \\
\hline T:2 & 2.9 & 2.6 & & 2.6 & 2.5 \\
\hline Tedian & 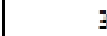 & 3 & . & 3 & 3 \\
\hline mode & 3 & 3 & . & 3 & 3 \\
\hline std.dev & 0.5 & 0.8 & & 0.8 & 0.8 \\
\hline min & 1 & 1 & & 1 & 1 \\
\hline$\pi 2 x$ & $\vdots$ & 3 & . & 3 & 3 \\
\hline
\end{tabular}

\begin{tabular}{|c|c|c|c|c|c|}
\hline & 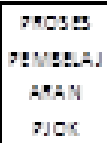 & 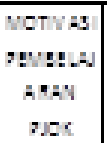 & 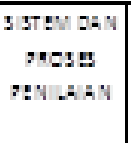 & \begin{tabular}{|l|} 
mos:s \\
rev La \\
an
\end{tabular} & $\begin{array}{l}\text { R:vath } \\
\text { :LAdA, }\end{array}$ \\
\hline 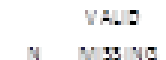 & & 20 & 20 & $s$ & $z$ \\
\hline$m: x$ & 2. & 2.7 & 2.8 & $2:$ & $2=$ \\
\hline medir & & : & $:$ & t & : \\
\hline med: & g & : & : & : & : \\
\hline 128.68 & 0.7 & $0:=$ & 277 & 0.78 & 0.78 \\
\hline min & & $:$ & $:$ & $:$ & : \\
\hline$-T_{x}$ & g & : & : & : & : \\
\hline
\end{tabular}

Tabel 4. Motivasi Peserta Didik

\begin{tabular}{|c|c|c|c|c|c|}
\hline & & Frequency & Percent & $\begin{array}{c}\text { Valid } \\
\text { percent }\end{array}$ & $\begin{array}{c}\text { Cumulative } \\
\text { percent }\end{array}$ \\
\hline \multirow{4}{*}{ Valid } & $\mathrm{Ya}$ & 29 & 96.7 & 96.7 & \multirow{4}{*}{100.0} \\
\hline & Tidak & & & & \\
\hline & Lainnya & 1 & 3.3 & 3.3 & \\
\hline & Total & 30 & 100.0 & 100.0 & \\
\hline & & Frequency & Percent & $\begin{array}{c}\text { Valid } \\
\text { percent }\end{array}$ & $\begin{array}{c}\text { Cumulative } \\
\text { percent }\end{array}$ \\
\hline \multirow{4}{*}{ Valid } & Ya & 25 & 83.3 & 83.3 & \multirow{4}{*}{$\begin{array}{r}83.3 \\
90 \\
100.0\end{array}$} \\
\hline & Tidak & 2 & 6.7 & 6.7 & \\
\hline & Lainnva & 3 & 10 & 10 & \\
\hline & Total & 30 & 100.0 & 100.0 & \\
\hline & & Frequency & Percent & $\begin{array}{c}\text { Valid } \\
\text { percent }\end{array}$ & $\begin{array}{c}\text { Cumulative } \\
\text { percent }\end{array}$ \\
\hline \multirow{4}{*}{ Valid } & Ya & 29 & 96.7 & 96.7 & \multirow{4}{*}{100.0} \\
\hline & Tidak & & & & \\
\hline & Lainnya & 1 & 3.3 & 3.3 & \\
\hline & Total & 30 & 100.0 & 100.0 & \\
\hline & & Frequency & Percent & $\begin{array}{c}\text { Valid } \\
\text { percent }\end{array}$ & $\begin{array}{c}\text { Cumulative } \\
\text { percent }\end{array}$ \\
\hline \multirow{4}{*}{ Valid } & Ya & 26 & 86.7 & 86.7 & \multirow{4}{*}{$\begin{array}{r}86.7 \\
93.4 \\
100.0\end{array}$} \\
\hline & Tidak & 2 & 6.7 & 6.7 & \\
\hline & Lainnya & 2 & 6.7 & 6.7 & \\
\hline & Total & 30 & 100.0 & 100.0 & \\
\hline & & Frequency & Percent & $\begin{array}{c}\text { Valid } \\
\text { percent }\end{array}$ & $\begin{array}{l}\text { Cumulative } \\
\text { percent }\end{array}$ \\
\hline \multirow{4}{*}{ Valid } & Ya & 27 & 90 & 90 & \multirow{4}{*}{$\begin{array}{r}90 \\
96.7 \\
100.0\end{array}$} \\
\hline & Tidak & 2 & 6.7 & 6.7 & \\
\hline & Lainnya & 1 & 3.3 & 3.3 & \\
\hline & Total & 30 & 100.0 & 100.0 & \\
\hline & & Frequency & Percent & $\begin{array}{c}\text { Valid } \\
\text { percent }\end{array}$ & $\begin{array}{c}\text { Cumulative } \\
\text { percent }\end{array}$ \\
\hline \multirow{4}{*}{ Valid } & Ya & 29 & 96.7 & 96.7 & \multirow{4}{*}{100.0} \\
\hline & Tidak & 10 & & & \\
\hline & Lainnya & 1 & $\begin{array}{r}3.3 \\
1000\end{array}$ & $\begin{array}{r}3.3 \\
1000\end{array}$ & \\
\hline & Total & & & & \\
\hline
\end{tabular}


Motivasi Peserta Didik Sekolah Dasar Dalam Pembelajaran Pendidikan Jasmani Olahraga Dan

Kesehatan Selama Masa Pandemi

E-ISSN: 2722-3450 P-ISSN: 2775-3808

Tabel 5. Metode pembelajaran

\begin{tabular}{|c|c|c|c|c|c|}
\hline & & Frequency & Percent & $\begin{array}{c}\text { Valid } \\
\text { percent }\end{array}$ & $\begin{array}{c}\text { Cumulative } \\
\text { percent }\end{array}$ \\
\hline \multirow{3}{*}{ Valid } & \begin{tabular}{|l|} 
Ya \\
Tidak
\end{tabular} & 6 & 20 & 20 & \multirow{3}{*}{100.0} \\
\hline & Lainnya & 24 & 80 & 80 & \\
\hline & Total & 30 & 100.0 & 100.0 & \\
\hline & & Frequency & Percent & $\begin{array}{c}\text { Valid } \\
\text { percent }\end{array}$ & $\begin{array}{c}\text { Cumulative } \\
\text { percent }\end{array}$ \\
\hline \multirow{4}{*}{ Valid } & & 23 & 76.7 & 76.7 & \multirow{4}{*}{$\begin{array}{r}76.7 \\
93.4 \\
100.0\end{array}$} \\
\hline & Tidak & 5 & 16.7 & 16.7 & \\
\hline & Lainnya & 2 & 3.3 & 3.3 & \\
\hline & Total & & 100.0 & 100.0 & \\
\hline & & Frequency & Percent & $\begin{array}{c}\text { Valid } \\
\text { percent }\end{array}$ & $\begin{array}{c}\text { Cumulative } \\
\text { percent }\end{array}$ \\
\hline \multirow{4}{*}{ Valid } & & 23 & \begin{tabular}{|l|}
76.7 \\
\end{tabular} & 76.7 & \multirow{4}{*}{$\begin{array}{r}76.7 \\
86.7 \\
100.0\end{array}$} \\
\hline & Tidak & 3 & 10 & 10 & \\
\hline & Lainnya & 4 & 13.3 & 13.3 & \\
\hline & Total & 30 & 100.0 & 100.0 & \\
\hline & & Frequency & Percent & $\begin{array}{c}\text { Valid } \\
\text { percent }\end{array}$ & $\begin{array}{c}\text { Cumulative } \\
\text { percent }\end{array}$ \\
\hline \multirow{3}{*}{ Valid } & & 24 & 80 & 80 & \multirow{3}{*}{100.0} \\
\hline & Tidak & 6 & 20 & 20 & \\
\hline & $\begin{array}{l}\text { Lainnya } \\
\text { Total }\end{array}$ & 30 & 100.0 & 100.0 & \\
\hline & & Frequency & Percent & $\begin{array}{c}\text { Valid } \\
\text { percent }\end{array}$ & $\begin{array}{c}\text { Cumulative } \\
\text { percent }\end{array}$ \\
\hline \multirow{4}{*}{ Valid } & & 24 & 80 & 80 & \multirow{4}{*}{$\begin{array}{r}80 \\
93.3 \\
100.0\end{array}$} \\
\hline & Tidak & 4 & 13.3 & 13.3 & \\
\hline & Lainnya & 2 & 6.7 & 6.7 & \\
\hline & Total & 30 & 100.0 & 100.0 & \\
\hline & & Frequency & Percent & $\begin{array}{c}\text { Valid } \\
\text { percent }\end{array}$ & $\begin{array}{c}\text { Cumulative } \\
\text { percent }\end{array}$ \\
\hline \multirow{4}{*}{ Valid } & & 27 & 90 & 90 & \multirow{4}{*}{$\begin{array}{r}90 \\
96.7 \\
100.0\end{array}$} \\
\hline & Tidak & 2 & 6.7 & 6.7 & \\
\hline & Lainnya & 1 & 3.3 & 3.3 & \\
\hline & Total & 30 & 100.0 & 100.0 & \\
\hline
\end{tabular}

Tabel 6. Kesesuaian materi pembelajaran

\begin{tabular}{|c|c|c|c|c|c|}
\hline & & Frequency & Percent & $\begin{array}{c}\text { Valid } \\
\text { percent }\end{array}$ & $\begin{array}{c}\text { Cumulative } \\
\text { percent }\end{array}$ \\
\hline \multirow[t]{2}{*}{ Valid } & \begin{tabular}{|l|} 
Ya \\
Tidak \\
Lainnya \\
Total
\end{tabular} & $\begin{array}{l}15 \\
15 \\
30\end{array}$ & $\begin{array}{r}50 \\
50 \\
100.0\end{array}$ & $\begin{array}{r}50 \\
50 \\
100.0\end{array}$ & $\begin{array}{r}50 \\
100.0\end{array}$ \\
\hline & & Frequency & Percent & $\begin{array}{c}\text { Valid } \\
\text { percent }\end{array}$ & $\begin{array}{c}\text { Cumulative } \\
\text { percent }\end{array}$ \\
\hline \multirow[t]{2}{*}{ Valid } & \begin{tabular}{|l|} 
Ya \\
Tidak \\
Lainnya \\
Total
\end{tabular} & \begin{tabular}{r|}
19 \\
8 \\
3 \\
30
\end{tabular} & $\begin{array}{r}63.3 \\
26.7 \\
10 \\
100.0\end{array}$ & $\begin{array}{r}63.3 \\
26.7 \\
10 \\
100.0\end{array}$ & $\begin{array}{r}63.3 \\
90 \\
100.0\end{array}$ \\
\hline & & Frequency & Percent & $\begin{array}{c}\text { Valid } \\
\text { percent }\end{array}$ & $\begin{array}{c}\text { Cumulative } \\
\text { percent }\end{array}$ \\
\hline \multirow[t]{2}{*}{ Valid } & \begin{tabular}{|l|} 
Ya \\
Tidak \\
Lainnya \\
Total
\end{tabular} & \begin{tabular}{r|}
27 \\
1 \\
2 \\
30 \\
\end{tabular} & $\begin{array}{r}90 \\
3.3 \\
6.7 \\
100.0 \\
\end{array}$ & $\begin{array}{r}90 \\
3.3 \\
6.7 \\
100.0\end{array}$ & $\begin{array}{r}90 \\
93.3 \\
100.0\end{array}$ \\
\hline & & Frequency & Percent & $\begin{array}{c}\text { Valid } \\
\text { percent }\end{array}$ & $\begin{array}{c}\text { Cumulative } \\
\text { percent }\end{array}$ \\
\hline \multirow[t]{2}{*}{ Valid } & \begin{tabular}{|l|} 
Ya \\
Tidak \\
Lainnya \\
Total \\
\end{tabular} & $\begin{array}{r}2 \\
30\end{array}$ & $\begin{array}{r}93.3 \\
6.7 \\
100.0 \\
\end{array}$ & $\begin{array}{r}93.3 \\
6.7 \\
100.0 \\
\end{array}$ & $\begin{array}{r}93.3 \\
100.0 \\
\end{array}$ \\
\hline & & Frequency & Percent & $\begin{array}{c}\text { Valid } \\
\text { percent }\end{array}$ & $\begin{array}{c}\text { Cumulative } \\
\text { percent }\end{array}$ \\
\hline \multirow[t]{2}{*}{ Valid } & \begin{tabular}{|l|} 
Ya \\
Tidak \\
Lainnya \\
Total \\
\end{tabular} & 30 & 100.0 & 100.0 & $\begin{array}{r}100 \\
100.0 \\
\end{array}$ \\
\hline & & Frequency & Percent & $\begin{array}{c}\text { Valid } \\
\text { percent }\end{array}$ & $\begin{array}{c}\text { Cumulative } \\
\text { percent }\end{array}$ \\
\hline Valid & $\begin{array}{l}\text { Ya } \\
\text { Tidak } \\
\text { Lainnya } \\
\text { Total }\end{array}$ & \begin{tabular}{r|}
27 \\
2 \\
1 \\
30
\end{tabular} & $\begin{array}{r}90 \\
6.7 \\
3.3 \\
100.0\end{array}$ & $\begin{array}{r}90 \\
6.7 \\
3.3 \\
100.0\end{array}$ & $\begin{array}{r}90 \\
96.7 \\
100.0\end{array}$ \\
\hline
\end{tabular}

Tabel 7. Media pembelajaran

\begin{tabular}{|c|c|c|c|c|c|}
\hline & & Frequency & Percent & $\begin{array}{c}\text { Valid } \\
\text { percent }\end{array}$ & $\begin{array}{c}\text { Cumulative } \\
\text { percent }\end{array}$ \\
\hline \multirow{4}{*}{ Valid } & Whatsaap grup & 23 & 76.7 & 76.7 & \multirow{4}{*}{$\begin{array}{r}76.7 \\
80 \\
100.0\end{array}$} \\
\hline & Zoom & 1 & 3.3 & 3.3 & \\
\hline & Lainnya & 6 & 20 & 20 & \\
\hline & Total & 30 & 100.0 & 100.0 & \\
\hline & & Frequency & Percent & $\begin{array}{c}\text { Valid } \\
\text { percent }\end{array}$ & $\begin{array}{l}\text { Cumulative } \\
\text { percent }\end{array}$ \\
\hline \multirow{4}{*}{ Valid } & Ya & 28 & 93.3 & 93.3 & \multirow{4}{*}{$\begin{array}{r}93.3 \\
96.3 \\
100.0\end{array}$} \\
\hline & Tidak & 1 & 3.3 & 3.3 & \\
\hline & Lainnya & 1 & 3.3 & 3.3 & \\
\hline & Total & 30 & 100.0 & 100.0 & \\
\hline & & Frequency & Percent & $\begin{array}{c}\text { Valid } \\
\text { percent }\end{array}$ & $\begin{array}{l}\text { Cumulative } \\
\text { percent }\end{array}$ \\
\hline \multirow{4}{*}{ Valid } & $\mathrm{Ya}$ & 29 & 96.7 & 96.7 & \multirow[t]{2}{*}{96.7} \\
\hline & Tidak & 1 & 3.3 & 3.3 & \\
\hline & Lainnya & & & & \multirow{2}{*}{100.0} \\
\hline & Total & 30 & 100.0 & 100.0 & \\
\hline & & Frequency & Percent & $\begin{array}{c}\text { Valid } \\
\text { percent }\end{array}$ & $\begin{array}{l}\text { Cumulative } \\
\text { percent }\end{array}$ \\
\hline \multirow{4}{*}{ Valid } & $\mathrm{Ya}$ & 28 & 93.3 & 93.3 & 93.3 \\
\hline & Tidak & 2 & 6.7 & 6.7 & \\
\hline & Lainnya & & & & \multirow[t]{2}{*}{100.0} \\
\hline & Total & 30 & 100.0 & 100.0 & \\
\hline & & Frequency & Percent & $\begin{array}{c}\text { Valid } \\
\text { percent }\end{array}$ & $\begin{array}{l}\text { Cumulative } \\
\text { percent }\end{array}$ \\
\hline \multirow{4}{*}{ Valid } & Ya & 29 & 96.7 & 96.7 & \multirow[t]{4}{*}{96.7} \\
\hline & Tidak & & & & \\
\hline & Lainnya & 1 & 3.3 & 3.3 & \\
\hline & Total & 30 & 100.0 & 100.0 & \\
\hline & & Frequency & Percent & $\begin{array}{c}\text { Valid } \\
\text { percent }\end{array}$ & $\begin{array}{c}\text { Cumulative } \\
\text { percent }\end{array}$ \\
\hline \multirow{3}{*}{ Valid } & \begin{tabular}{|l|} 
Ya \\
Tidak
\end{tabular} & 27 & 90 & 90 & \multirow{3}{*}{100.0} \\
\hline & Lainnya & 3 & 10 & 10 & \\
\hline & Total & 30 & 100.0 & 100.0 & \\
\hline
\end{tabular}

Tabel 8. Partisipasi peserta didik

\begin{tabular}{|c|c|c|c|c|c|}
\hline & & Frequency & Percent & $\begin{array}{c}\text { Valid } \\
\text { percent }\end{array}$ & $\begin{array}{c}\text { Cumulative } \\
\text { percent }\end{array}$ \\
\hline \multirow[t]{2}{*}{ Valid } & $\begin{array}{l}\text { Peserta didik antusias dan berpartisipasi dengan baik } \\
\text { Peserta didik tidak memperhatikan pembelajaran } \\
\text { Lainnya } \\
\text { Total }\end{array}$ & \begin{tabular}{r|r}
28 \\
1 \\
1 \\
30
\end{tabular} & \begin{tabular}{r|r|}
93.3 \\
3.3 \\
3.3 \\
100.0
\end{tabular} & $\begin{array}{r}93.3 \\
3.3 \\
3.3 \\
100.0\end{array}$ & $\begin{array}{r}93.3 \\
96.6 \\
100.0\end{array}$ \\
\hline & & Frequency & Percent & $\begin{array}{c}\begin{array}{c}\text { Valid } \\
\text { percent }\end{array} \\
\end{array}$ & $\begin{array}{c}\text { Cumulative } \\
\text { percent }\end{array}$ \\
\hline \multirow[t]{2}{*}{ Valid } & $\begin{array}{l}\text { Ya } \\
\text { Tidak } \\
\text { Lainnya } \\
\text { Total }\end{array}$ & \begin{tabular}{r|r}
24 \\
4 \\
2 \\
30
\end{tabular} & \begin{tabular}{r|}
80 \\
13.3 \\
6.7 \\
100.0
\end{tabular} & \begin{tabular}{r|r}
80 \\
13.3 \\
6.7 \\
100.0
\end{tabular} & $\begin{array}{r}80 \\
93.3 \\
100.0\end{array}$ \\
\hline & & Frequency & Percent & $\begin{array}{c}\text { Valid } \\
\text { percent }\end{array}$ & $\begin{array}{l}\text { Cumulative } \\
\text { percent }\end{array}$ \\
\hline \multirow[t]{2}{*}{ Valid } & $\begin{array}{l}\text { Ya } \\
\text { Tidak } \\
\text { Lainnya } \\
\text { Total }\end{array}$ & \begin{tabular}{r|r|}
21 \\
4 \\
5 \\
30
\end{tabular} & \begin{tabular}{r|}
70 \\
13.3 \\
16.7 \\
100.0
\end{tabular} & \begin{tabular}{r|}
70 \\
13.3 \\
16.7 \\
100.0
\end{tabular} & $\begin{array}{r}70 \\
83.3 \\
100.0\end{array}$ \\
\hline & & Frequency & Percent & $\begin{array}{c}\text { Valid } \\
\text { percent }\end{array}$ & $\begin{array}{l}\text { Cumulative } \\
\text { percent }\end{array}$ \\
\hline \multirow[t]{2}{*}{ Valid } & \begin{tabular}{|l} 
Ya \\
Tidak \\
Lainnya \\
Total \\
\end{tabular} & $\begin{array}{r}28 \\
2\end{array}$ & $\begin{array}{r}93.3 \\
6.7 \\
100.0 \\
\end{array}$ & $\begin{array}{r}93.3 \\
6.7 \\
100.0\end{array}$ & $\begin{array}{c}93.3 \\
100.0\end{array}$ \\
\hline & & Frequency & Percent & $\begin{array}{c}\text { Valid } \\
\text { percent }\end{array}$ & $\begin{array}{l}\text { Cumulative } \\
\text { percent }\end{array}$ \\
\hline \multirow[t]{2}{*}{ Valid } & $\begin{array}{l}\text { Ya } \\
\text { Tidak } \\
\text { Lainnya } \\
\text { Total }\end{array}$ & \begin{tabular}{r|r}
27 & \\
1 \\
1 \\
30
\end{tabular} & \begin{tabular}{r|}
90 \\
3.3 \\
3.3 \\
100.0 \\
\end{tabular} & \begin{tabular}{r|}
90 \\
3.3 \\
3.3 \\
100.0
\end{tabular} & $\begin{array}{r}90 \\
93.3 \\
100.0\end{array}$ \\
\hline & & Frequency & Percent & $\begin{array}{c}\text { Valid } \\
\text { percent }\end{array}$ & $\begin{array}{l}\text { Cumulative } \\
\text { percent }\end{array}$ \\
\hline Valid & \begin{tabular}{|l|} 
Ya \\
Tidak \\
Lainnya \\
Total
\end{tabular} & 30 & 100.0 & 100 & 100.0 \\
\hline
\end{tabular}


Tabel 9. Proses pembelajaran PJOK

\begin{tabular}{|c|c|c|c|c|c|}
\hline & & Frequency & Percent & $\begin{array}{c}\text { Valid } \\
\text { percent }\end{array}$ & $\begin{array}{c}\text { Cumulative } \\
\text { percent }\end{array}$ \\
\hline \multirow{3}{*}{ Valid } & Bekerjasama dengan orang tua peserta didik & 28 & 66.7 & 66.7 & \multirow{3}{*}{$\begin{array}{r}66.7 \\
100.0\end{array}$} \\
\hline & Memberi tutorial melalui video atau power point & 1 & 33.3 & 33.3 & \\
\hline & & 30 & 100.0 & 100.0 & \\
\hline & & Frequency & Percent & $\begin{array}{c}\text { Valid } \\
\text { percent }\end{array}$ & $\begin{array}{c}\text { Cumulative } \\
\text { percent }\end{array}$ \\
\hline \multirow{3}{*}{ Valid } & Ya & 30 & 100 & 100 & \multirow{3}{*}{100} \\
\hline & Tidak & & & & \\
\hline & $\begin{array}{l}\text { Ladminya } \\
\text { Total }\end{array}$ & 30 & 100.0 & 100.0 & \\
\hline & & Frequency & Percent & $\begin{array}{c}\text { Valid } \\
\text { percent }\end{array}$ & $\begin{array}{c}\text { Cumulative } \\
\text { percent }\end{array}$ \\
\hline \multirow{3}{*}{ Valid } & Ya & 30 & 100 & 100 & \multirow{3}{*}{$\begin{array}{r}100 \\
100.0\end{array}$} \\
\hline & $\begin{array}{l}\text { Tidak } \\
\text { Lainnya }\end{array}$ & & & & \\
\hline & Total & 30 & 100.0 & 100.0 & \\
\hline & & Frequency & Percent & $\begin{array}{c}\text { Valid } \\
\text { percent }\end{array}$ & $\begin{array}{c}\text { Cumulative } \\
\text { percent }\end{array}$ \\
\hline \multirow{4}{*}{ Valid } & Ya & 28 & 93.3 & 93.3 & \multirow{4}{*}{$\begin{array}{r}93.3 \\
96.6 \\
100.0\end{array}$} \\
\hline & Tidak & 1 & 3.3 & 3.3 & \\
\hline & Lainnya & 1 & 3.3 & 3.3 & \\
\hline & Total & 30 & 100.0 & 100.0 & \\
\hline & & Frequency & Percent & $\begin{array}{c}\text { Valid } \\
\text { percent }\end{array}$ & $\begin{array}{c}\text { Cumulative } \\
\text { percent }\end{array}$ \\
\hline \multirow{4}{*}{ Valid } & Ya & 30 & 100 & 100 & \multirow{4}{*}{100.0} \\
\hline & Tidak & & & & \\
\hline & Lainnya & & & & \\
\hline & Total & 30 & 100.0 & 100.0 & \\
\hline & & Frequency & Percent & $\begin{array}{c}\text { Valid } \\
\text { percent }\end{array}$ & $\begin{array}{c}\text { Cumulative } \\
\text { percent }\end{array}$ \\
\hline \multirow{4}{*}{ Valid } & Ya & 26 & 86.7 & 86.7 & \multirow{4}{*}{$\begin{array}{r}86.7 \\
100.0\end{array}$} \\
\hline & Tidak & & 13.3 & 13.3 & \\
\hline & Lainnya & & & & \\
\hline & Total & 30 & 100.0 & 100.0 & \\
\hline
\end{tabular}

Tabel 10. Motivasi pembelajaran PJOK

\begin{tabular}{|c|c|c|c|c|c|}
\hline & & Frequency & Percent & $\begin{array}{c}\text { Valid } \\
\text { percent }\end{array}$ & $\begin{array}{c}\text { Cumulative } \\
\text { percent }\end{array}$ \\
\hline \multirow[t]{2}{*}{ Valid } & \begin{tabular}{|l|} 
Ya \\
Tidak \\
Lainnya \\
Total
\end{tabular} & 30 & 100.0 & $\begin{array}{r}100 \\
100.0\end{array}$ & $\begin{array}{r}100 \\
100.0\end{array}$ \\
\hline & & Frequency & Percent & $\begin{array}{c}\text { Valid } \\
\text { percent }\end{array}$ & $\begin{array}{c}\text { Cumulative } \\
\text { percent }\end{array}$ \\
\hline \multirow[t]{2}{*}{ Valid } & \begin{tabular}{|l} 
Ya \\
Tidak \\
Lainnya \\
Total
\end{tabular} & 30 & 100.0 & $\begin{array}{r}100 \\
100.0 \\
\end{array}$ & 100.0 \\
\hline & & Frequency & Percent & $\begin{array}{c}\text { Valid } \\
\text { percent }\end{array}$ & $\begin{array}{c}\text { Cumulative } \\
\text { percent }\end{array}$ \\
\hline \multirow[t]{2}{*}{ Valid } & \begin{tabular}{|l|} 
Ya \\
Tidak \\
Lainnya \\
Total
\end{tabular} & $\begin{array}{r}27 \\
3\end{array}$ & $\begin{array}{r}90 \\
10 \\
100.0\end{array}$ & $\begin{array}{r}90 \\
10 \\
100.0\end{array}$ & 100.0 \\
\hline & & Frequency & Percent & $\begin{array}{c}\text { Valid } \\
\text { percent }\end{array}$ & $\begin{array}{c}\text { Cumulative } \\
\text { percent }\end{array}$ \\
\hline \multirow[t]{2}{*}{ Valid } & \begin{tabular}{|l|} 
Ya \\
Tidak \\
Lainnya \\
Total \\
\end{tabular} & $\begin{array}{r}28 \\
1 \\
1 \\
30\end{array}$ & $\begin{array}{r}93.3 \\
3.3 \\
3.3 \\
100.0\end{array}$ & $\begin{array}{r}93.3 \\
3.3 \\
3.3 \\
100.0\end{array}$ & $\begin{array}{r}93.3 \\
96.6 \\
100.0\end{array}$ \\
\hline & & Frequency & Percent & $\begin{array}{c}\text { Valid } \\
\text { percent }\end{array}$ & $\begin{array}{c}\text { Cumulative } \\
\text { percent }\end{array}$ \\
\hline \multirow[t]{2}{*}{ Valid } & \begin{tabular}{|l|} 
Ya \\
Tidak \\
Lainnya \\
Total \\
\end{tabular} & $\begin{array}{r}24 \\
5 \\
1 \\
30\end{array}$ & $\begin{array}{r}80 \\
16.7 \\
3.3 \\
100.0\end{array}$ & $\begin{array}{r}80 \\
16.7 \\
3.3 \\
100.0\end{array}$ & $\begin{array}{r}80 \\
96.7 \\
100.0\end{array}$ \\
\hline & & Frequency & Percent & $\begin{array}{c}\text { Valid } \\
\text { percent }\end{array}$ & $\begin{array}{c}\text { Cumulative } \\
\text { percent }\end{array}$ \\
\hline Valid & \begin{tabular}{|l} 
Ya \\
Tidak \\
Lainnya \\
Total
\end{tabular} & $\begin{array}{r}28 \\
1 \\
1 \\
30\end{array}$ & $\begin{array}{r}93.3 \\
3.3 \\
3.3 \\
100.0\end{array}$ & $\begin{array}{r}93.3 \\
3.3 \\
3.3 \\
100.0\end{array}$ & $\begin{array}{r}93.3 \\
96.6 \\
100.0\end{array}$ \\
\hline
\end{tabular}

Tabel 11. Sistem dan proses penilaian

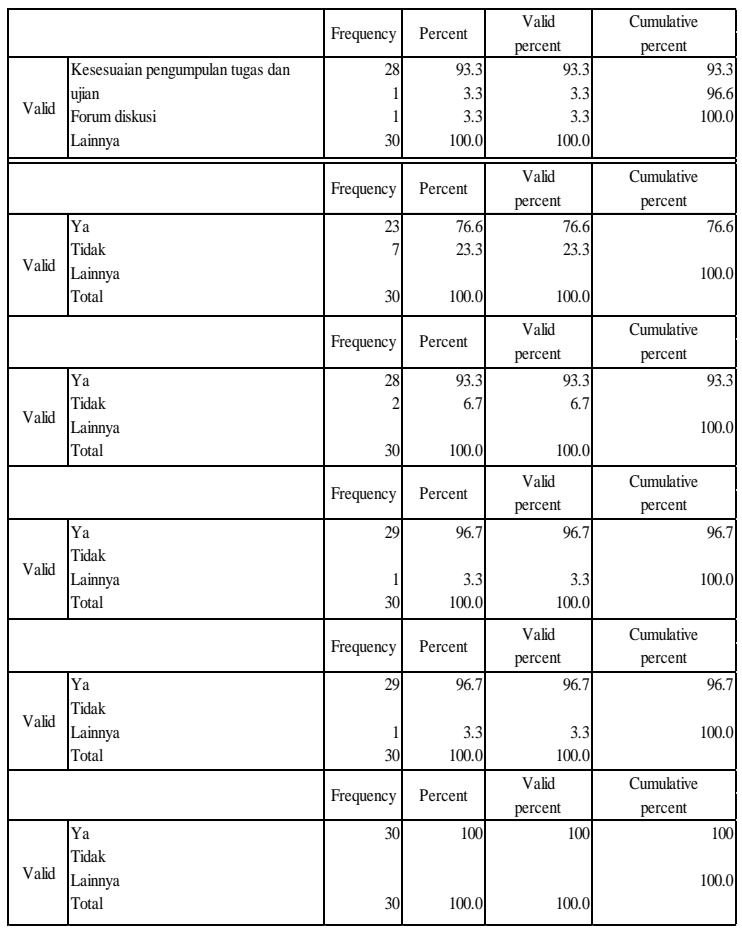

Tabel 12. Penilaian pembelajaran

\begin{tabular}{|c|c|c|c|c|c|}
\hline & & Frequency & Percent & $\begin{array}{c}\begin{array}{c}\text { Valid } \\
\text { percent }\end{array} \\
\end{array}$ & $\begin{array}{c}\text { Cumulative } \\
\text { percent }\end{array}$ \\
\hline \multirow{4}{*}{ Valid } & Penilaian terlaksana dengan baik & 18 & 60 & 60 & 60 \\
\hline & Penilaian kurang efektif & 10 & 33.3 & 33.3 & 93.3 \\
\hline & Lainnya & 2 & 6.7 & 6.7 & 100.0 \\
\hline & Total & 30 & 100.0 & 100.0 & \\
\hline & & Frequency & Percent & $\begin{array}{c}\text { Valid } \\
\text { percent }\end{array}$ & $\begin{array}{l}\text { Cumulative } \\
\text { percent }\end{array}$ \\
\hline \multirow{4}{*}{ Valid } & Ya & 22 & 73.3 & 73.3 & 73.3 \\
\hline & Tidak & 8 & 26.7 & 26.7 & \\
\hline & Lainnya & & & & 100.0 \\
\hline & Total & 30 & 100.0 & 100.0 & \\
\hline & & Frequency & Percent & $\begin{array}{l}\text { Valid } \\
\text { percent }\end{array}$ & $\begin{array}{c}\text { Cumulative } \\
\text { percent }\end{array}$ \\
\hline \multirow{4}{*}{ Valid } & Ya & 27 & 90 & 90 & 90 \\
\hline & Tidak & 3 & 10 & 10 & \\
\hline & Lainnya & & & & 100.0 \\
\hline & Total & 30 & 100.0 & 100.0 & \\
\hline & & Frequency & Percent & $\begin{array}{l}\text { Valid } \\
\text { percent }\end{array}$ & $\begin{array}{c}\text { Cumulative } \\
\text { percent }\end{array}$ \\
\hline \multirow{4}{*}{ Valid } & Ya & 27 & 90 & 90 & 90 \\
\hline & Tidak & 2 & 6.7 & 6.7 & 96.7 \\
\hline & Lainnya & 1 & 3.3 & 3.3 & 100.0 \\
\hline & Total & 30 & 100.0 & 100.0 & \\
\hline & & Frequency & Percent & $\begin{array}{c}\text { Valid } \\
\text { percent }\end{array}$ & $\begin{array}{l}\text { Cumulative } \\
\text { percent }\end{array}$ \\
\hline \multirow{4}{*}{ Valid } & Ya & 29 & 96.7 & 96.7 & 96.7 \\
\hline & Tidak & 1 & 3.3 & 3,3 & \\
\hline & Lainnya & & & & 100.0 \\
\hline & Total & 30 & 100.0 & 100.0 & \\
\hline & & Frequency & Percent & $\begin{array}{c}\text { Valid } \\
\text { percent }\end{array}$ & $\begin{array}{l}\text { Cumulative } \\
\text { percent }\end{array}$ \\
\hline \multirow{4}{*}{ Valid } & Ya & 20 & \begin{tabular}{l|l|}
66.7 \\
\end{tabular} & 66.7 & 66.7 \\
\hline & Tidak & 9 & 30 & 30 & \\
\hline & Lainnya & 1 & 3.3 & & 100.0 \\
\hline & Total & 30 & 100.0 & 100.0 & \\
\hline
\end{tabular}


Tabel 13. Kendala belajar

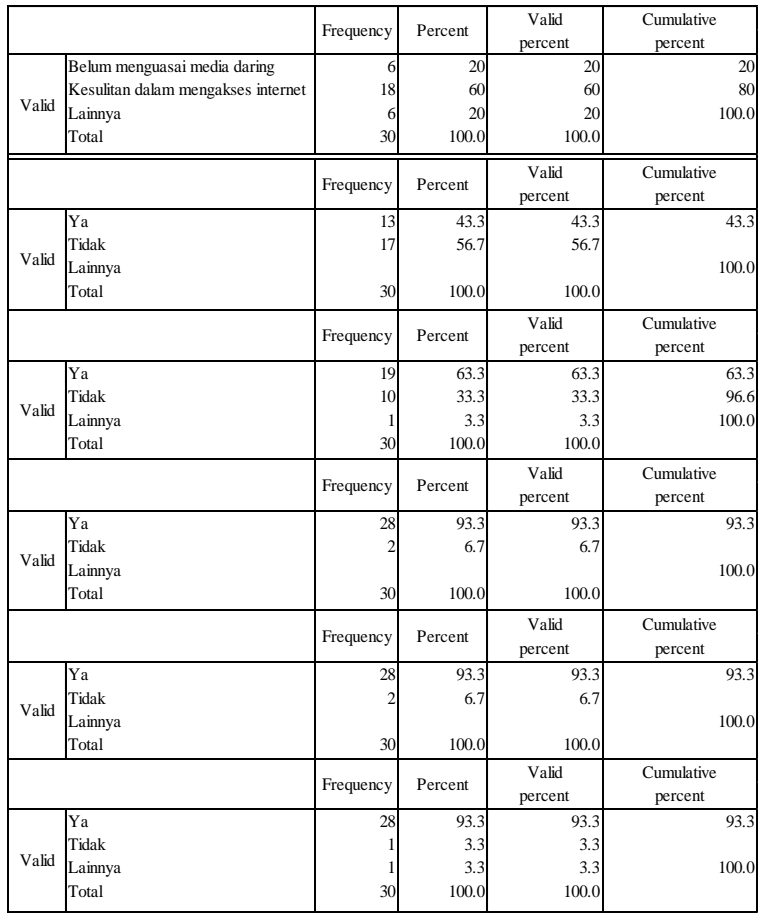

\section{Pembahasan}

Hasil penelitian menunjukan bahwa pada masa pandemi sekarang ini semua guru tetap melaksanakan kegiatan pembelajaran PJOK. Secara keseluruhan pelaksanaan pembelajaran PJOK menggunakan media daring dengan menyesuaikan materi pembelajaran sesuai dengan kondisi selama masa pandemi dan arahan dari pemerintah. Hal ini disesuaikan dengan Surat Edaran nomor 4 tahun 2020 tentang Pelaksanaan Pendidikan dalam Masa Darurat Pandemi COVID-19 yang menyatakan pemerintah memberlakukan kegiatan belajar secara daring dalam rangka pencegahan penyebaran virus COVID-19 (Indra \& Marheni, 2020).

Hasil penelitian pada indikator motivasi peserta didik menunjukan bahwa $100 \%$ guru tetap memberikan motivasi belajar kepada peserta didik selama masa pandemi lainnya memberikan jawaban dengan cara memberikan salam sehat dan semangat kepada pesera didik selama masa pandemi.

Hasil pada indikator metode pembelajaran menunjukkan bahwa 96,6\% guru menjawab dengan menggunakan metode pembelajaran daring dan memberikan jawaban lainnya berupa menggunakan video pembelajaran daring via whatsapp dan zoom meeting, PJJ melalui google classroom, berupa video pembelajaran, metode daring dan pembelajaran yang mudah dilakukan peserta didik, metode video dan materi agar peserta didik lebih bisa memahami materi yang diberikan, melalui whatsapp dan dividiokan lalu dikirim, dan tugas soal selama masa pandemi.

\section{Kesimpulan}

Motivasi bagi peserta didik tidak semata-mata muncul begitu saja pada diri peserta didik, peran seorang guru sangatlah penting untuk selalu memotivasi peserta didik selama masa pandemi. Motivasi belajar merupakan kekuatan yang dimiliki oleh peserta didik yang berasal dari dalam diri maupun dari luar diri peserta didik yang kemudian dapat mendorong peserta didik untuk mencapai sebuah tujuan 
tertentu yang telah ditetapkan sebelumnya.

Dalam pelaksanaan pembelajaran PJOK motivasi belajar sangatlah dibutuhkan agar siswa dapat melaksanakan aktivitas psikomotorik dengan maksimal, hal ini dikarenakan dalam proses pembelajaran PJOK motivasi mempunyai peranan yang penting karena objek pembelajaran PJOK yang merupakan gerak manusia yaitu pelajar atau peserta didik itu sendiri.

\section{Daftar Pustaka}

Ceruso, R., Esposito, G., \& D’Elia, F. (2019). Analysis and evaluation of the qualitative aspects of the young players. Journal of Physical Education and Sport, 19(5), 18141819.

https://doi.org/10.7752/jpes.2019.s52 $\underline{66}$

Firman, F., \& Rahayu, S. (2020). Pembelajaran Online di Tengah Pandemi Covid-19. Indonesian Journal of Educational Science (IJES), 2(2), 81-89. https://doi.org/10.31605/ijes.v2i2.659

Fitriyani, Y., Fauzi, I., \& Sari, M. Z. (2020). Motivasi Belajar Mahasiswa Pada Pembelajaran Daring Selama Pandemik Covid-19. Jurnal Kependidikan: Jurnal Hasil Penelitian Dan Kajian Kepustakaan Di, $\quad$ 6(2), 165-175. https://doi.org/10.23917/ppd.v7i1.109 $\underline{73}$

Handayani, D., Hadi, D. R., Isbaniah, F., Burhan, E., \& Agustin, H. (2020). Corona Virus Disease 2019. Jurnal Respirologi Indonesia, 40(2), 119129.

http://jurnalrespirologi.org/index.php/ jri/article/view/101

Hardiono, B. (2018). Efektifitas Model Latihan Kekuatan Badgan Terhadap Keberhasilan Pemanjatan pada Olahraga Panjat Dinding untuk Pemanjat Pemula. Jurnal Ilmu Keolahragaan, 17(1), 50-57.

Hardiyono, B. (2020). Tingkat Kecemasan Sebelum Bertanding Dan Percaya Diri Pada Saat Bertanding Atlet Pelatda Pengprov Fpti Sumatera Selatan. Kinestetik, 4(1), 47-54. https://doi.org/10.33369/jk.v4i1.1039 $\underline{9}$

Herlina, H., \& Suherman, M. (2020). Potensi Pembelajaran Pendidikan Jasmani Olahraga Dan Kesehatan (Pjok) Di Tengah Pandemi Corona Virus Disease (Covid)-19 Di Sekolah Dasar. Tadulako Journal Sport Sciences And Physical Education, $8(1)$, $1-7$.

http://jurnal.untad.ac.id/jurnal/index.p $\underline{\mathrm{hp} / \mathrm{PJKR} / \text { article/view/16186 }}$

Hidayat, A. (2019). Effect of agility ladder 
exercises on agility of participants

extracurricular futsal at Bina Darma

University. Journal of Physics:

Conference Series, 1402(5).

https://doi.org/10.1088/1742-

6596/1402/5/055003

Huang, W. Y., \& Hsu, C. C. (2019).

Research on the motivation and attitude of college students' physical education in Taiwan. Journal of Physical Education and Sport, 19(1), 69-79.

https://doi.org/10.7752/jpes.2019.s10 $\underline{11}$

Indra, P., \& Marheni, E. (2020). Jurnal Performa Olahraga. Performa Olahraga, 5(1), 39-47.

Kusmiyanti, D., Kristiyanto, A., Utomo, T. A., \& History, A. (2018). Motivation to Community for Following Aerobic Sports. ACTIVE: Journal of Physical Education, Sport, Health and Recreation, $\quad 7(2), \quad 78-82$. https://doi.org/10.15294/active.v7i2.2 $\underline{3111}$

Mariani, A. M., Marcolongo, F., Melchiori, F. M., \& Cassese, F. P. (2019). Mental skill training to enhance sport motivation in adolescents. Journal of Physical Education and Sport, 19(5), 19081913.

https://doi.org/10.7752/jpes.2019.s52
Priono, J. (2021). Implementasi Pembelajaran PJOK Pada masa pandemi Covid-19 di Mts sekecamatan sei balai kabupaten batu bara provinsi sumatra utara. Jurnal Penkaslesrek, 8(1), 32-45. https://doi.org/10.46244/penjaskesrek . $\mathrm{v} 8 \mathrm{i} 1.1367$

Sugiyono. (2015). Metode Penelitian. In Metode Penelitian. Bandung: Alfabeta.

Susilo, A., Rumende, C. M., Pitoyo, C. W., Santoso, W. D., Yulianti, M., Sinto, R., Singh, G., Nainggolan, L., Nelwan, E. J., Khie, L., Widhani, A., Wijaya, E., Wicaksana, B., Maksum, M., Annisa, F., Jasirwan, O. M., \& Yunihastuti, E. (2020). Coronavirus

Disease 2019: Tinjauan Literatur Terkini Coronavirus Disease 2019: Review of Current Literatures. Jurnal Penyakit Dalam Indonesia, 7(1), 4567.

\section{https://doi.org/10.7454/jpdi.v7i1.415} Undang-undang RI No. 20, 2003, U. R. N. 20 T. (2003). Undang-Undang Republik Indonesia Nomor 20 Tahun 2003 Tentang Sistem Pendidikan Nasional Dengan Rahmat Tuhan Yang Maha Esa Presiden Republik Indonesia. Zitteliana. 